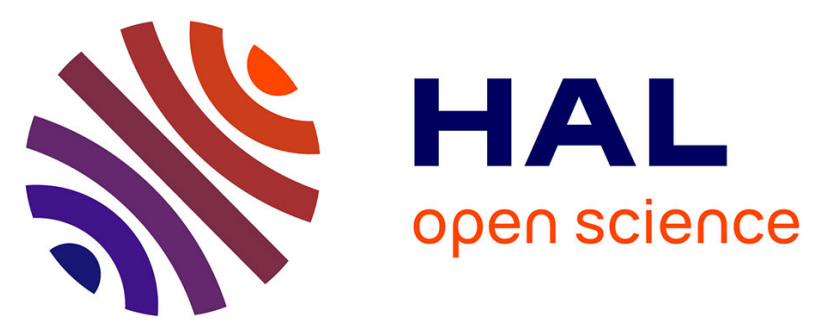

\title{
Ex-situ solid electrolyte interphase synthesis via radiolysis of Li-ion battery anode-electrolyte system for improved coulombic efficiency
}

Fanny Varenne, D. Ortiz, J P Alper, F. Miserque, A Boulineau, J.-F Martin, S. Franger, N. Herlin-Boime, M. Mostafavi, S. Le Caer

\section{To cite this version:}

Fanny Varenne, D. Ortiz, J P Alper, F. Miserque, A Boulineau, et al.. Ex-situ solid electrolyte interphase synthesis via radiolysis of Li-ion battery anode-electrolyte system for improved coulombic efficiency. 14th Tihany Symposium on Radiation Chemistry, May 2019, Siofok, Hungary. cea02327868

\section{HAL Id: cea-02327868 https: / hal-cea.archives-ouvertes.fr/cea-02327868}

Submitted on 23 Oct 2019

HAL is a multi-disciplinary open access archive for the deposit and dissemination of scientific research documents, whether they are published or not. The documents may come from teaching and research institutions in France or abroad, or from public or private research centers.
L'archive ouverte pluridisciplinaire HAL, est destinée au dépôt et à la diffusion de documents scientifiques de niveau recherche, publiés ou non, émanant des établissements d'enseignement et de recherche français ou étrangers, des laboratoires publics ou privés. 


\title{
EX SITU SOLID ELECTROLYTE INTERPHASE SYNTHESIS VIA RADIOLYSIS OF LI-ION BATTERY ANODE-ELECTROLYTE SYSTEM FOR IMPROVED COULOMBIC EFFICIENCY
}

\author{
F. Varenne ${ }^{1}$, D. Ortiz ${ }^{1}$, J. P. Alper ${ }^{1}$, F. Miserque ${ }^{2}$, A. Boulineau ${ }^{3}$, J.-F. Martin ${ }^{3}$, S. \\ Franger $^{4}$, N. Herlin-Boime ${ }^{1}$, M. Mostafavi ${ }^{5}$, S. Le Caër ${ }^{1}$ \\ ${ }^{1}$ NIMBE, UMR 3685 CEA, CNRS, Université Paris-Saclay, \\ CEA Saclay F-91191 Gif-sur-Yvette Cedex, France \\ ${ }^{2}$ DEN, SCCME, CEA, Université Paris-Saclay F-91191 Gif-sur-Yvette Cedex, France \\ ${ }^{3}$ CEA, LITEN F-38054 Grenoble Cedex 9, France \\ ${ }^{4}$ ICMMO, UMR 8182, CNRS \\ Université Paris-Saclay, F-91405 Orsay Cedex, France \\ ${ }^{5}$ LCP UMR 8000, Université Paris Saclay, F-91400 Orsay Cedex, France
}

Lithium-ion batteries (LIBs) are very efficient energy storage devices. Recently we demonstrated that the highly reactive species generated by radiolysis of an electrolyte are the same as those generated during the cycling of LIBs using similar solvents. ${ }^{[1-3]}$ Furthermore, radiolysis generated these species in measurable amounts at time scales significantly shorter than electrochemical cycling in a battery cell (minutes vs. days) and enabled proposing reaction mechanisms and measuring rate constants. ${ }^{[1-3]}$ The electrolytes used in LIBs are however not stable at the working potential of Li-ion anode materials. Thus, during the first cycles of the battery, the electrolyte decomposes at the anode surface producing a solidelectrolyte interphase (SEI) which is vital to device performance and safety. We have also extended the radiolysis approach to study the chemical processes at the anode-electrolyte interface and investigate ex-situ generation of SEI. Indeed, the energy cost for the SEI production is very high. For instance, days and weeks are required at the energy plant in order to form a proper SEI on the surface of the anode electrodes. We have demonstrated the radiolytic growth of an SEI with a chemical composition similar to that formed during electrochemical cycling, as determined by XPS. The quantity of the SEI increases with increasing irradiation dose. Degradation products formed in the liquid and gas phase are also identified as matching those formed during electrochemical cycling. TEM results support the XPS results of increasing SEI content with increasing irradiation dose. Electrochemical characterization by galvanostatic cycling of test cells indicates that the radiolysis generated SEI greatly improves first cycle efficiency of the materials assembled in half cells, and impedance spectroscopy supports the result with an increase in resistivity observed for irradiated samples. This first study opens the door to the use of irradiation tools for the artificial generation of an SEI and for producing LIB anode materials with improved performance. $^{[4]}$

\section{References}

[1] D. Ortiz et al., Nature Comm., 2015, 6, 6950.

[2] D. Ortiz et al., ChemSusChem, 2015, 8, 3605.

[3] D. Ortiz et al., J. Power Sources, 2016, 326, 285.

[4] F. Varenne et al., Sustainable Energy \& Fuels, 2018, 2, 2100. 